\title{
Knockout of an outer membrane protein operon of Anaplasma marginale by transposon mutagenesis
}

\author{
Francy L Crosby ${ }^{1 *}$, Heather L Wamsley ${ }^{2}$, Melanie G Pate ${ }^{2}$, Anna M Lundgren', Susan M Noh³,
} Ulrike G Munderloh ${ }^{4}$ and Anthony F Barbet ${ }^{1}$

\begin{abstract}
Background: The large amounts of data generated by genomics, transcriptomics and proteomics have increased our understanding of the biology of Anaplasma marginale. However, these data have also led to new assumptions that require testing, ideally through classical genetic mutation. One example is the definition of genes associated with virulence. Here we describe the molecular characterization of a red fluorescent and spectinomycin and streptomycin resistant A. marginale mutant generated by Himar1 transposon mutagenesis.

Results: High throughput genome sequencing to determine the Himar1-A. marginale genome junctions established that the transposon sequences were integrated within the coding region of the omp10 gene. This gene is arranged within an operon with AM1225 at the 5' end and with omp9, omp8, omp7 and omp6 arranged in tandem at the $3^{\prime}$ end. RNA analysis to determine the effects of the transposon insertion on the expression of omp 10 and downstream genes revealed that the Himar1 insertion not only reduced the expression of omp10 but also that of downstream genes. Transcript expression from omp9, and omp8 dropped by more than $90 \%$ in comparison with their counterparts in wild-type A. marginale. Immunoblot analysis showed a reduction in the production of Omp9 protein in these mutants compared to wild-type A. marginale.
\end{abstract}

Conclusions: These results demonstrate that transposon mutagenesis in A. marginale is possible and that this technology can be used for the creation of insertional gene knockouts that can be evaluated in natural host-vector systems.

\section{Background}

Anaplasma marginale is a tick-borne and obligate intracellular bacterium that causes bovine anaplasmosis, a disease that has gained particular attention due to the considerable economic losses for the cattle industry [1-4]. Onset of clinical disease is mainly characterized by a severe hemolytic anemia $[1,2]$. Cattle that survive acute infection become carriers of $A$. marginale and organisms can be transmitted to susceptible cattle mechanically or by tick bite [2]. A. marginale persists in carrier cattle because of its capability to subvert the immune system using antigenic variation in which different variants of

\footnotetext{
*Correspondence: crosbyl@ufl.edu

${ }^{1}$ College of Veterinary Medicine, University of Florida, Department of Infectious Diseases and Pathology, 2015 SW 16th avenue, Gainesville, FL 32610, USA

Full list of author information is available at the end of the article
}

outer membrane proteins such as Msp2 and Msp3 are expressed [5-8].

Work on the development of a preventive vaccine against this disease began in the early 1900's with the isolation of $A$. marginale subsp. centrale $[9,10]$. This less virulent strain, originally from South Africa, is used for immunization of cattle in Africa, Australia, South America and the Middle East and remains the most widely-used and practical vaccine against bovine anaplasmosis [9-11]. This vaccine is not approved in the United States because of the risk of transmitting contaminant blood-borne pathogens that will infect cattle [1]. Recently, comparative genomic studies demonstrated that proteins that are conserved in US strains were not conserved in $A$. marginale subsp. centrale [10-12].

Different vaccination methods have been developed for the control of bovine anaplasmosis that range from 
attenuated live or killed organisms, to DNA and recombinant protein vaccines [9]. But A. marginale derived from cell culture, killed organisms and DNA vaccines induce only partial protection [13-15]. Immunization trials using outer membrane proteins or a complex of linked or unlinked outer membrane proteins of $A$. marginale derived from erythrocytes have demonstrated good protection against high bacteremia, anemia and homologous strain challenge [16-20]. However, to promote long lasting protection, several immunization boosts may be required and in addition to this, production and purification of these components is time-consuming and expensive.

The increased use of molecular approaches such as whole genome, RNA sequencing, proteomics and comparative genomics of $A$. marginale has identified potential virulence-associated targets that can be altered or removed by reverse genetics techniques [12,21-25]. This could allow the creation of attenuated organisms that have reduced pathogenicity but still elicit cellular and antibody responses that stimulate immunity without causing disease. Consequently the development of genetic tools to transform $A$. marginale and generate in-vitro gene knockouts, or insertional mutants that can be tested for attenuation in their in-vivo environment is of great significance.

One way to create insertional mutations in pathogenic bacteria is via transposon mutagenesis, in which a library of recombinant bacteria containing different transposon insertions can be created, allowing for the screening of mutant strains with diverse phenotypes [26,27]. The Himar1 transposon is a non-replicative class II DNA transposon that is a member of the Tc1/mariner family and is often used for the creation of insertional mutants. Since these types of transposons are horizontally transferred between species, they do not have host restricted functions, making them suitable for use in a wide-range of eukaryotic and prokaryotic hosts [27,28]. In addition to this, the Himar1 transposon does not have DNA target specificity since it is integrated randomly in TA dinucleotide sites [28-30]. Because of these advantages, transposon mutagenesis using this system has been successfully developed in other tick-borne pathogens such as Rickettsia rickettsii, Coxiella burnetii, Borrelia burgdorferi, Francisella tularensis, Ehrlichia chaffeensis and Anaplasma phagocytophilum [31-40]. These previous results suggest that this system could be useful for the transformation of $A$. marginale.

Nevertheless, previous attempts to transform $A$. marginale by transposon mutagenesis were not successful. Previously, the Himarl transposon and transposase were delivered in two separate vectors into $A$. marginale which resulted in the isolation of green fluorescent and antibiotic resistant bacteria. However molecular characterization of these recombinant organisms established that the entire plasmid carrying the transposon sequences was integrated into the A. marginale chromosome by a single crossover homologous recombination mechanism instead of the classical cut and paste mechanism of transposition [41]. Therefore, we wanted to evaluate first, if classical transposon mutagenesis using the Himarl transposon system is achievable in A. marginale, and second, if transposon mutagenesis using this system, is useful for the creation of insertional knockout mutations.

\section{Results}

Transformation of Anaplasma marginale by transposon mutagenesis

Attempts to transform A. marginale by transposon mutagenesis using the Himarl transposon/transposase system delivered in two separate plasmids were not successful. The probability that two plasmids are introduced at once into $A$. marginale organisms could be very low, especially when viability in the extracellular environment might be highly compromised, resulting in a low fraction of cells competent to take up DNA.

Therefore in order to promote transposon mutagenesis in these bacteria, the transposase was provided in cis with the Himar1 transposon sequences (R. F. Felsheim unpublished data). The pHimarcisA7mCherry-SS contains the hyperreactive allele $A 7$ transposase and the Himar1 TIR flanking the $m$ Cherry reporter gene and the $\operatorname{aad} A$ gene, which confers resistance against spectinomycin and streptomycin. Expression of the transposase and the reporter and antibiotic selection genes is driven by the $A$. marginale $t r$ promoter $[41,42]$ (Figure 1A). Antibiotic selection pressure of electroporated bacteria with this construct resulted in the isolation of red fluorescent and antibiotic resistant bacteria (Figure 1B).

\section{Mapping of transposon insertion within the $A$. marginale chromosome}

We used Roche/454 and Illumina high-throughput genome sequencing to determine: 1) the location of plasmid sequences within the $A$. marginale chromosome, 2) the recombination mechanism that allowed the segregation of mutant bacteria and 3) if these recombinant organisms correspond to a population containing insertions in different genomic locations or in a single genome site.

Mutations produced by the integration of the Himar1 transposon into the $A$. marginale chromosome will generate new junction sequences that are absent in the wild-type. These new sequences should include the Himarl terminal inverted repeats (TIR) followed by the sequence of the regions in which the transposon is integrated. Based on this, the strategy that we used to map the Himarl insertion site involved 
A

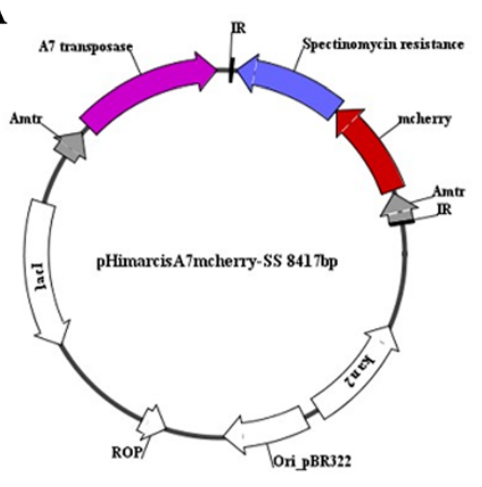

B
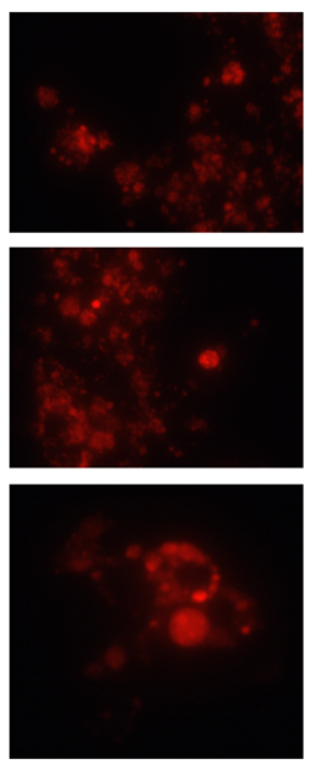
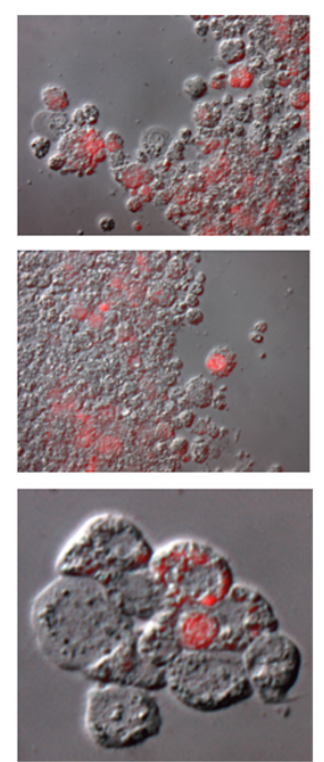

Figure 1 Red fluorescent A. marginale. A. Plasmid map of pHimarcisA7mCherry-SS used for the electroporation of A. marginale str. Virginia. B. Fluorescent (left) and phase contrast/fluorescence merged (right) images, of transformed A. marginale replicating in ISE6 tick cells.

alignment of the sequencing reads obtained by Roche/454 and Illumina methods to two reference sequences, the A. marginale str. St Maries genome sequence (CP000030) and the Himar1 TIR sequence. The Himar1 TIR-A. marginale genome junctions were identified by extracting reads that aligned to the $A$. marginale genome at one end and to the Himar1 TIR at the other end.

Analysis using Illumina reads mapped the Himar1 TIR-A. marginale genome junctions into a region of omp6 and omp10 genes. Interestingly these reads contained the same mutated sequence. The omp 6 and omp10 genes share a large stretch of identity $456 \mathrm{nt} /$ 459 nt (99\%) [43]. The short, 100 nt length of the Illumina reads, made it difficult to differentiate which gene contained the Himarl transposon. Additional analysis using longer reads obtained on the Roche/ 454 platform revealed that the Himarl transposon was integrated within the omp10 gene. These reads contained a region of omp10 that is not shared with omp6. Based on this sequencing analysis the genomic location of the Himarl transposon in the chromosome of the transformed A. marginale, is at position 245 considering 1 as the first base of the omp10 start codon (Figure 2A).

These results were verified by PCR amplification of gDNA from ISE6 cells infected with wild-type and transformed A. marginale using omp6 and omp 10 specific primers (Figure 2A-B). The size of omp6 amplicons (492 bp) in wild-type and transformed $A$. marginale was the same. However the size of the omp10 amplicon in transformed A. marginale was increased by 1836 bp when compared to the wild-type (969 bp), indicating that the transposon was integrated within the omp10 gene.

The genome sequence of $A$. marginale str. Virginia is available only as unannotated contigs with gaps. Therefore for our analysis we used the A. marginale str. St Maries genome as reference. For this reason we wanted to confirm that the transposon location in the mutated Virginia strain was the same as the one mapped in the reference genome. For this, combined Roche/454 and Illumina reads were assembled and a contig of 21,324 nucleotides identified. Alignment of this contig with the A. marginale str. St Maries genome showed that this sequence contained part of omp10 and upstream genes (99\% identity) (Figure 3) and that the transposon insertion site in the A. marginale str. Virginia matches the same region mapped using the reference genome.

Further analysis of sequencing reads determined that there is only one transposon insertion in the chromosome of recombinant $A$. marginale. The reads containing the Himar1 TIR-A. marginale junctions aligned to a single genome site. Although these transformed organisms were not cloned, data suggest that they are isogenic for the transposon insertion site within the omp10 gene. 
A.

\section{A. marginale}

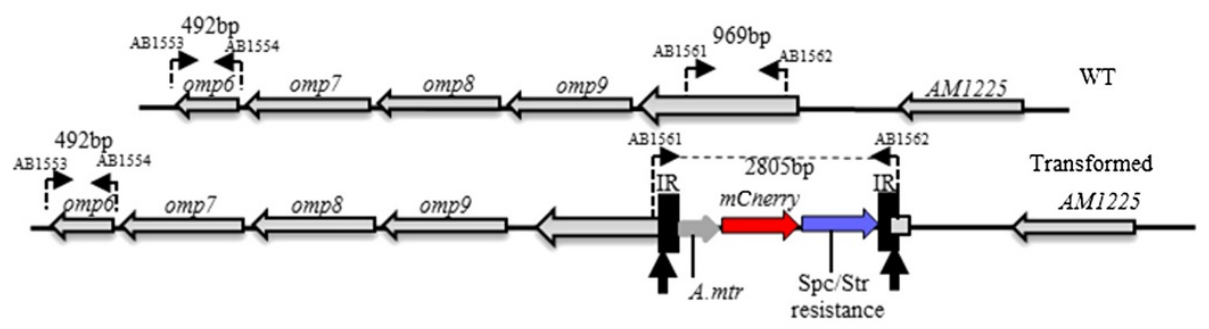

B.

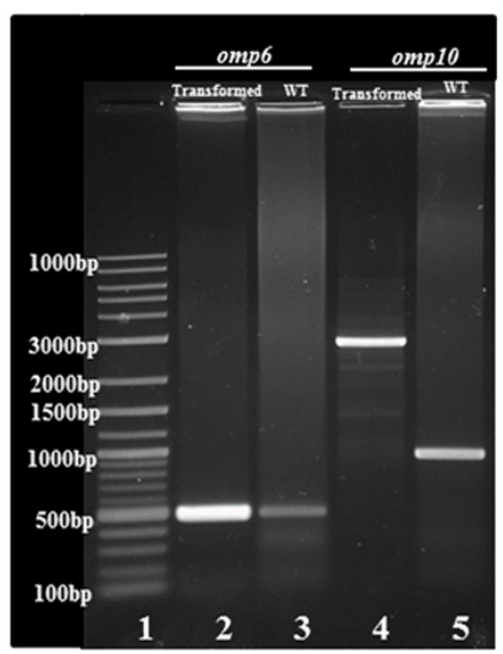

Figure 2 Mapping of Himar1 transposon insertion site. A. Location of primer pairs (AB1553-AB1554) and (AB1561-AB1562) designed to target the omp6 and omp10 genes respectively, in wild-type (WT) and transformed A. marginale. Based on sequencing results the Himarl sequences are integrated in the chromosome of transformed A. marginale at nucleotide 245 after the first base of the omp 10 start codon (arrows) and mCherry and $\operatorname{aadA}$ (Str/Spc resistant) genes are in the opposite orientation to omp10. B. Agarose Gel electrophoresis. gDNA isolated from ISE6 tick cells infected with wild-type (WT) and transformed A. marginale, was used as template for PCR amplification with primers shown in A. (Lane 1) 100 bp/1 Kb DNA ladder, omp6 amplicons in transformed (lane 2) and WT (lane3) A. marginale were of the same size $492 \mathrm{bp}$. The omp 10 amplicon in transformed A. marginale (lane 4) was 2805 bp, while in wild type was 969 bp (lane 5).

The mobilization of the Himar1 transposon from one locus to another is mediated by a transposase using a cut and paste mechanism $[27,30]$. It has been shown previously in other organisms that the Himarl transposon integrates preferentially into a TA site and leads to duplication of this dinucleotide upon integration into the target site [30]. This was found to be true also for $A$. marginale. Sequencing analysis revealed that the Himar1 transposon targeted a TA dinucleotide in omp10 (Figure 4A) and upon integration it is flanked by a TA dinucleotide sequence (Figure 4B). Thus, the mobilization of the Himar1 transposon into the omp10 gene of A. marginale was mediated by means of the $A 7$ transposase in a cut and paste mechanism. This transformant of $A$. marginale will be referred to as omp10::himar1 mutant.

\section{Evidence for expression of omp10 as part of an operon}

We hypothesize that the transposon insertion could alter the expression of omp10 and downstream genes. This hypothesis is based on recent work in which the transcriptome profile of $A$. marginale using RNAseq indicated that omp10 is expressed as part of a six-gene operon in erythrocytes of infected cattle [25]. This operon includes $A M 1225$, omp10, omp 9 , omp8, omp 7 and omp6 (Figure 5A).

Because of this, we wanted to determine if omp10 is expressed within a polycistronic message in A. marginale replicating in ISE6 tick cells. The intergenic region between $A M 1225$ and omp10 is $440 \mathrm{bp}$ long, while intergenic regions between omp10-9, omp9-8, omp8-7 and omp7-6 are $62 \mathrm{bp}, 63 \mathrm{bp}, 64 \mathrm{bp}$ and 36 bp respectively (Figure 5A). To test whether AM1225 through omp7 are expressed as a single transcriptional unit, total RNA isolated from ISE6 cells infected with wild-type $A$. marginale was reverse transcribed and template cDNA was used for amplification of intergenic regions with primers that connect neighboring genes (Figure 5A). The omp6 


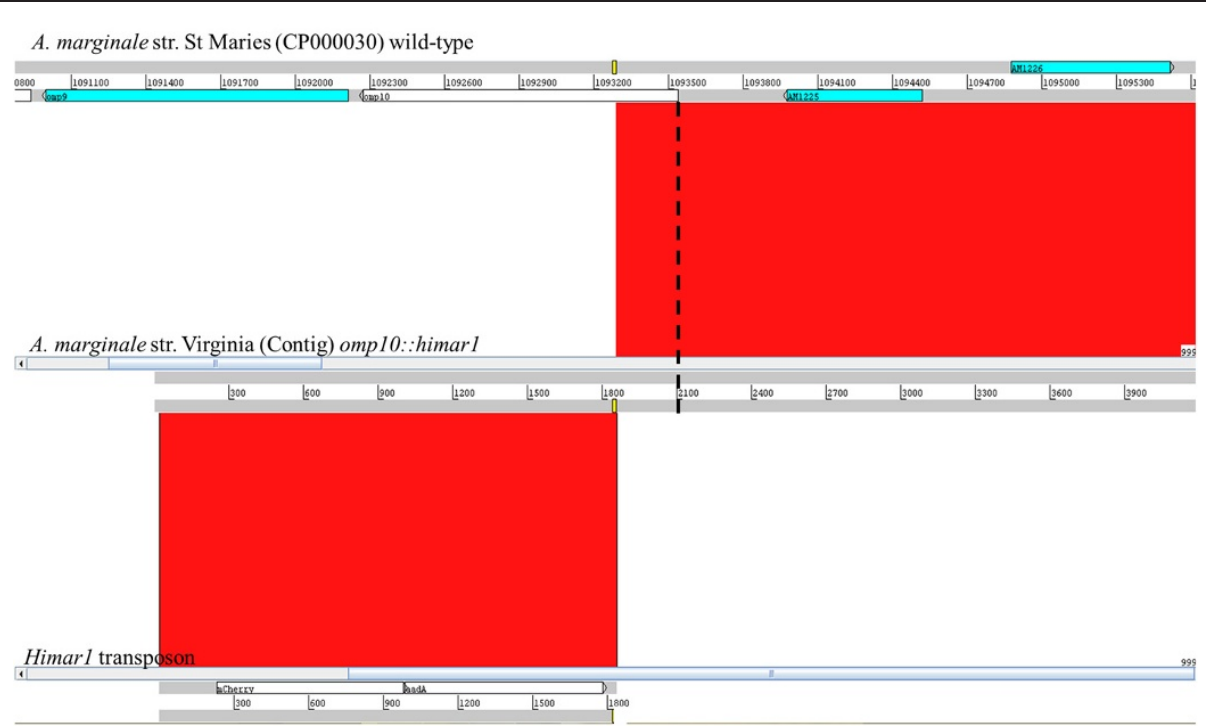

Figure 3 Himar1 transposon insertion site in the A. marginale str. Virginia genome. ACT (Artemis Comparison Tool) window showing alignment between the A. marginale genome (CP000030) used as reference, the A. marginale str. Virginia omp 10::himar1 contig formed by Roche/454 and Illumina sequencing reads and the Himar1 transposon sequences. Alignment between the A. marginale str St Maries and the omp10::himar1 mutant shows that sequences flanking the transposon insertion site are highly similar sharing an identity of $99 \%$ (matching red band). This demonstrates that the transposon insertion site (yellow boxes) occurred at nucleotide 245 after the first base of the omp10 start codon (black dotted line) in the reference strain. Alignment with the Himar1 transposon sequences clearly show the insertion of these sequences in the omp10::himar1 mutant which are not present in the A. marginale str. St Maries (absence of matching band).

gene was not included in these experiments, because previous work [43] and work in our lab showed that transcripts from this gene are not detected in A. marginale during infection of tick cells. Appropriate size amplicons of the intergenic regions between omp7-8, omp8-9, omp9-10 and omp10-AM1225 gene were detected (Figure $5 \mathrm{~B}$ ), providing evidence that these genes are transcribed as a single mRNA in A. marginale infected tick cells.

\section{RNA transcript analysis}

Next, we determined if insertion of the Himar1 sequences resulted in alteration of omp10 expression and the expression of genes downstream. For this, total RNA from ISE6 tick cells infected with A. marginale wild-type and omp10::himar1 mutant was reverse transcribed and cDNA used as template for PCR amplification with specific primers that were designed to anneal to omp6, omp7, omp8, omp9, and omp10 in wild-type and omp10::himar1 mutant respectively (Figure 6A). The omp10, 9, 8, and 7 genes, but not omp6, are transcriptionally active in wild-type A. marginale, although at low levels (Figure 6B). The Himar1 transposon insertion into the coding sequence of omp10, disrupted its expression and that of omp9, $o m p 8$, and omp 7 since transcripts from these genes were not detected in omp10::himar1 mutants of
A. marginale by this method (Figure 6B). To ensure integrity, cDNA samples from $A$. marginale wild-type and omp10::himar1 mutant were used for amplification with specific primers of a region of 131 bp of the 165 rRNA. Amplicons from this region were detected in both wild-type and omp10::himar1 mutant. No bands were visualized in negative controls (Figure 6B).

Since omp10 through omp 7 are expressed at low levels in ISE6 tick cells, RT-qPCR was used to quantitatively determine differences of expression between $A$. marginale wild-type and omp10::himar1 mutant. For this, cDNA generated from ISE6 tick cells infected with A. marginale wild-type and omp10::himar mutant was used for real time PCR amplification using primers and probes targeting omp8, omp 9 , and the 3' and 5' ends of omp10 (Figure 7A).

In order to compare these gene expression results between wild-type and omp10:himar1 A. marginale, $\mathrm{Ct}$ values were normalized to the rpoH, msp5 and $16 \mathrm{~S}$ rRNA genes. Changes in expression of these genes were calculated by the $2^{-\Delta \Delta C t}$ method, and results were expressed as percentage of expression, with a $100 \%$ expression level being assigned to the calibrator or control group, which in this case is wild-type A. marginale.

Although three different reference genes were used, RT-qPCR data normalization led to similar results in 


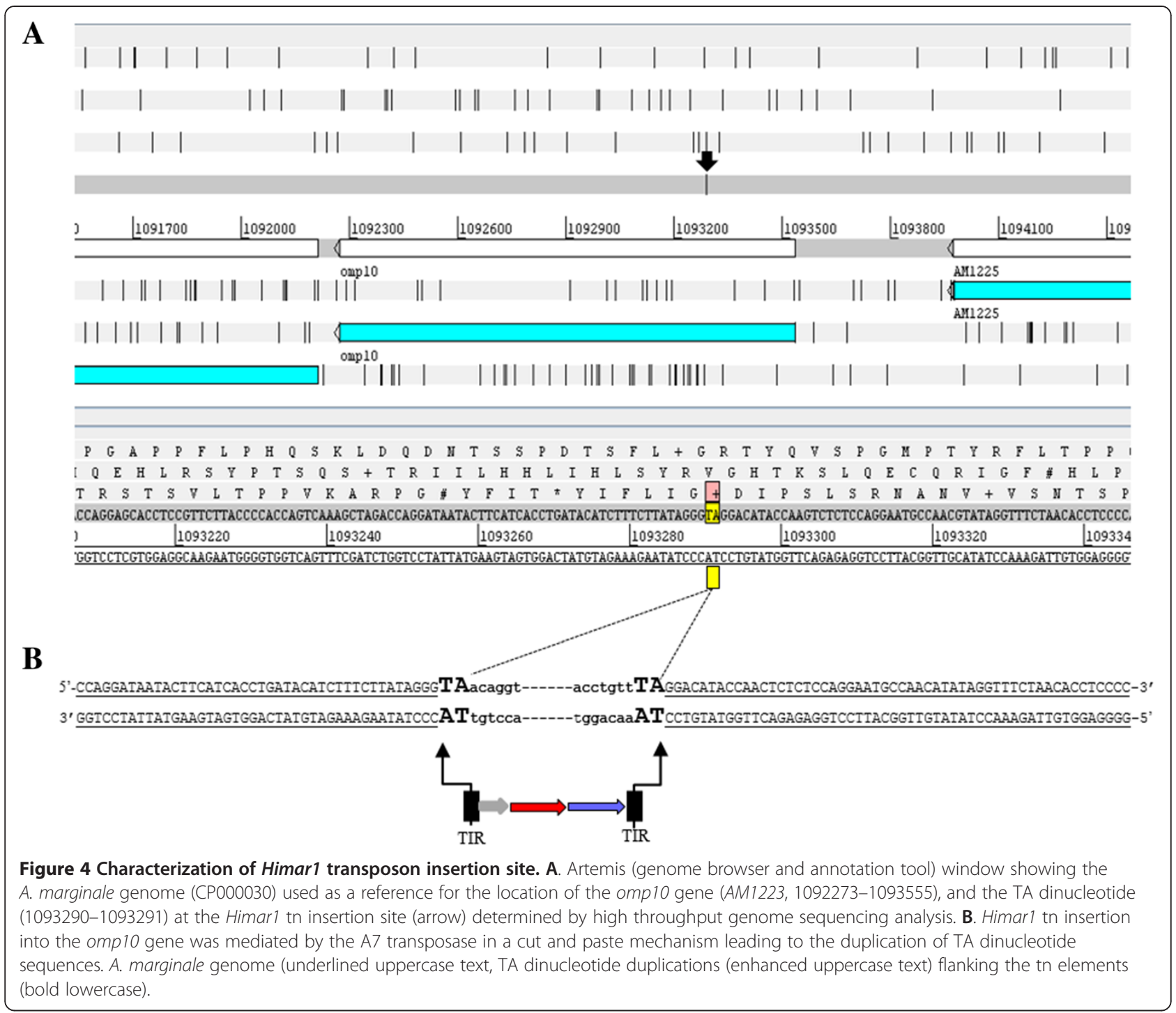

which there was a significantly reduced expression for omp 8 (97-99\%), omp9 (90-99\%) and omp10 3' end (85-98\%) relative to their counterparts in wildtype A. marginale (Figure 7B). These results show that Himarl transposon insertion into omp10 affected its expression and the expression of genes downstream, confirming the results obtained by RT-PCR and agarose gel electrophoresis. A second experiment investigated the possibility of the same effect occurring in regions of omp10 before the Himar1 transposon insertion site. For this, a primer and probe set was designed to anneal with a region at the 5' end of omp10 (Figure 7A). Even though there was a significant reduction in the detection of transcripts from this region (27-57\%) relative to the 5 ' end of omp10 in wild-type, this reduction was not as great as with the sequences located in omp10 downstream of the Himarl transposon insertion site.

\section{Western immunoblot analysis}

To determine if the decreased expression of mRNA in genes downstream of omp10 correlated with protein expression a Western immunoblot analysis using anti Omp9 antibody was performed.

To compare the protein expression of omp 9 between A. marginale omp10::himar1 and wild-type, the number of organisms per sample was quantified by qPCR using the opag 2 single copy gene to determine the copy number of $A$. marginale. Equal amounts $\left(10^{8}\right)$ of organisms of A. marginale wild-type and omp10::himar1 mutant were loaded per lane. A. marginale str. Virginia initial 


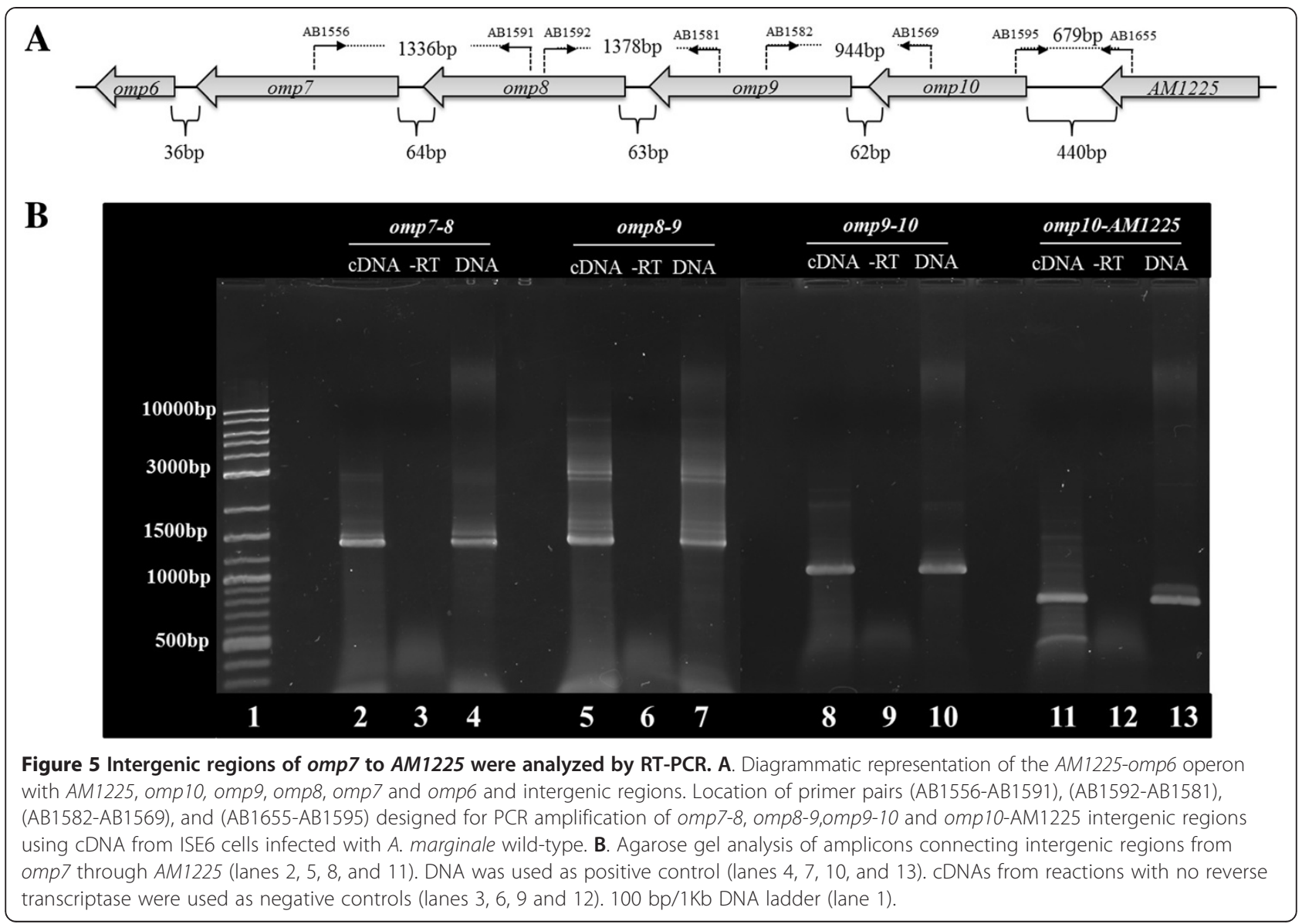

bodies and uninfected ISE6 cells were used as positive and negative controls respectively.

Western immunoblot showed a reduced expression of Omp9 in omp10::himar1 A. marginale mutant compared with wild-type (Figure 8A). The Omp9 band of $40 \mathrm{kDa}$ was present in wild-type and initial bodies but was not detected in the mutant or using negative control antibody Tryp1E1 (Figure 8B). Antibody F16C1 that reacts with major surface protein 5 (Msp5) was used as a loading control. Anti-Msp5 detected this protein $(19 \mathrm{kDa})$ in wild-type and omp10::himar1 A. marginale (Figure 8C).

These results correlated with results obtained from the RNA transcript analysis, showing that the transposon insertion severely affected the expression of both mRNA and protein from downstream genes such as omp 9 .

\section{Discussion}

The possibility of creating insertional mutations in $A$. marginale not only could provide a broad understanding of gene products required for infectivity, growth or viability of this pathogen in the mammalian host and the tick vector, but also would allow the generation of genetically attenuated organisms that can be tested in vaccination trials.
Here we report that transposon mutagenesis using the Himar1 transposon/transposase system for A. marginale is achievable and it could be useful for creating insertional mutations in these organisms. High throughput genome sequencing analysis for the characterization of these transformants established that transposon sequences are integrated within the omp10 gene of the $A$. marginale chromosome and its mobilization within this gene was mediated by the transposase in a cut and paste mechanism, since i.) the transposon sequences were integrated within a TA dinucleotide site ii.) upon integration of the transposon, this sequence was duplicated and is found flanking the transposon TIR at the junctions with the $A$. marginale genome and iii.) sequences from the delivering vector outside the transposon were not found.

Although these omp10::himar1 mutant organisms were not cloned, they are isogenic for the transposon insertion within the omp 10 because all the sequencing reads containing the transposon- $A$. marginale genome junctions aligned to the same genome site in the $A$. marginale/St. Maries reference genome sequence (CP000030). Possible reasons include transposon insertion into other genome regions that are essential for growth in tick cells, or 


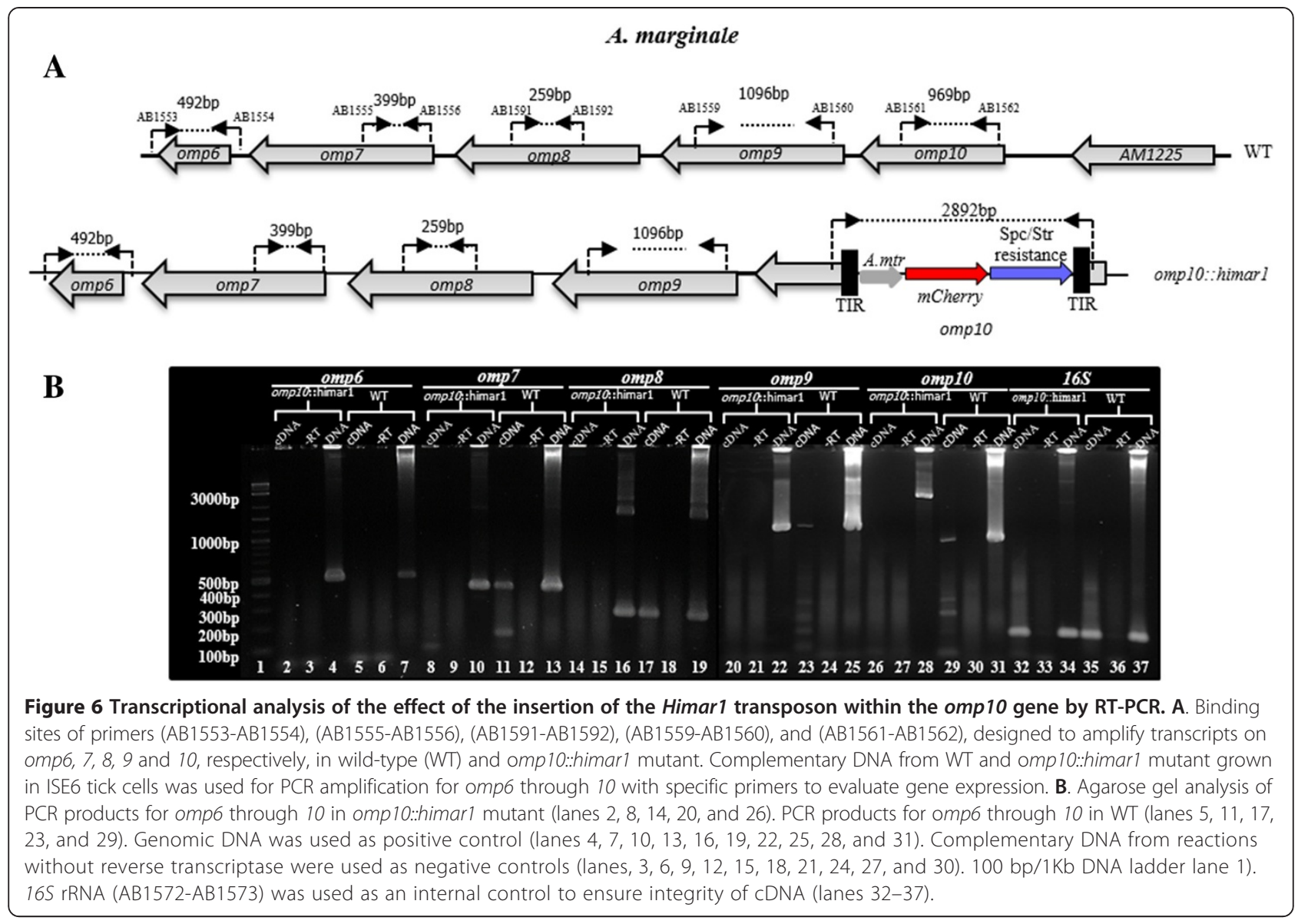

insertion into regions that cause slower growth and nonrecovery of these mutants. This suggests that further optimization is required to improve transformation efficiencies and for more rapid identification and separation of mutants before they are visible in cultures.

The omp10 gene is part of the omp1 through omp14 clusters, members of the msp2 superfamily that correspond to the pfam01617 family of bacterial surface antigens [21]. Deep sequencing of cDNA generated from total RNA of erythrocytes infected with $A$. marginale identified 70 putative operon arrangements. One contained omp10 transcribed as part of an operon of six genes with $A M 1225$ at the 5' end and with omp9, omp8, omp 7 and omp6 arranged in tandem at the 3' end [25]. In order to have a better understanding of the effects of the transposon insertion in omp10 on adjacent genes it was important to determine if omp10 is also expressed as part of a polycistronic message in $A$. marginale replicating in tick cell cultures.

RT-PCR of intergenic regions between omp7-8, omp8-9, omp9-10 and omp10-AM1225 provided evidence that omp10 is transcribed within a polycistronic message in $A$. marginale infected tick cells. However transcripts of omp6 were not detected. Similar results in which omp6 expression was not detected in A. marginale infected IDE8 tick cells and in tick midguts were obtained by others previously [43]. A lack of omp6 transcripts suggests that this gene may not be expressed in tick cells or only at very low levels. It has been shown that, in bacteria with reduced genomes such as Mycoplasma pneumoniae, gene members of an operon are not always expressed at the same levels and those genes distal from the promoter may have lower expression [44].

RT-PCR and relative gene expression experiments demonstrated that insertion of Himar1 into omp10 at nucleotide 245 from the start of the ORF altered the sequence of this gene. This resulted in the loss of its expression since there was a significant reduction in the detection of transcripts from this gene when compared with the expression of omp10 transcripts from wild-type A. marginale.

It has been shown that in bacteria production and/or stability of mRNA in regions downstream of a transposon insertion is greatly reduced, to the point where very little mRNA corresponding to this region can be isolated [45]. Insertion of Himar1 within a gene can affect the expression of neighboring genes, as shown in a variety of bacteria and especially in other tick-borne 

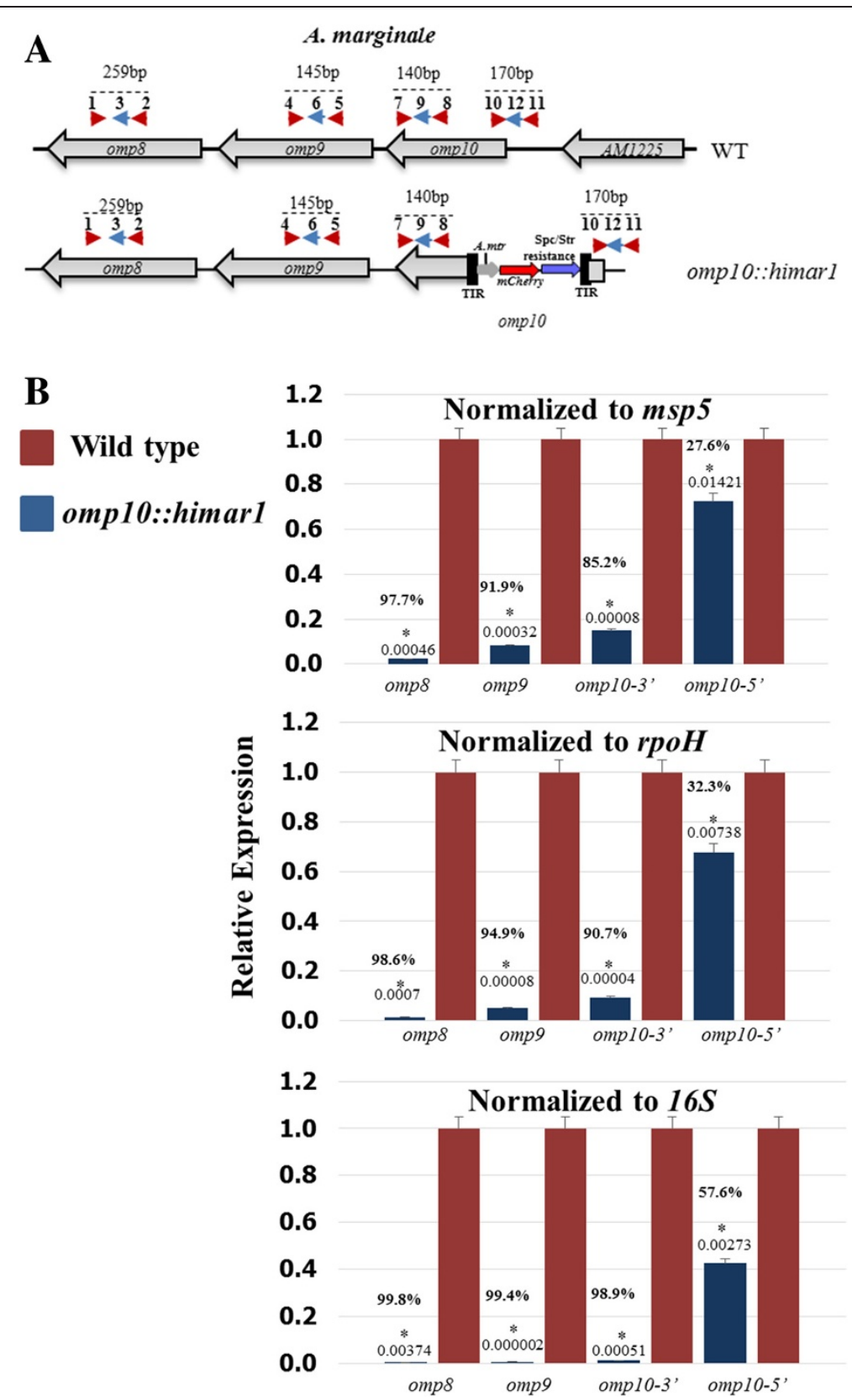

Figure 7 Relative gene expression by RT-qPCR. A. location of binding sites for primers and probes designed to target omp8 (1. AB1591, 2. AB1592, 3. AB1593), omp9 (4. AB1581, 5. AB1582, 6. AB1583), 3' end of omp10 (7. AB1569, 8. AB1570, 9. AB1571), and the $5^{\prime}$ end of omp10 (10. AB1594, 11. AB1595, 12. AB1596). B. Bar lengths represent the percentage of expression of omp8, omp9, $3^{\prime}$ end of omp 10 and $5^{\prime}$ end of omp 10 in A. marginale wild-type (red bars) and omp10::himar1 mutant (blue bars). msp5, rpoH and 165 rRNA were used as reference genes for data normalization. Changes in expression of these genes were calculated using the $2^{-\Delta \Delta C t}$ method.* Significant differences $(P<0.05)$ were calculated as described in materials and methods.

bacteria $[38,39,46]$. Therefore, we evaluated the effect of the Himarl insertion on the expression of genes downstream and upstream of omp10 in omp10::himar1 A. marginale. Results showed that the transcriptional activities of omp 9 and omp 8 were negatively influenced by the insertion of the Himarl within omp10 since detection of transcripts was significantly decreased in relation to wild-type omp 9 and omp 8 .

Although the transcription activity of regions upstream of the transposon insertion site at the 5' end of omp 10 dropped significantly in relation to wild-type $A$. marginale, it was not as severe as with genes downstream of omp10. 


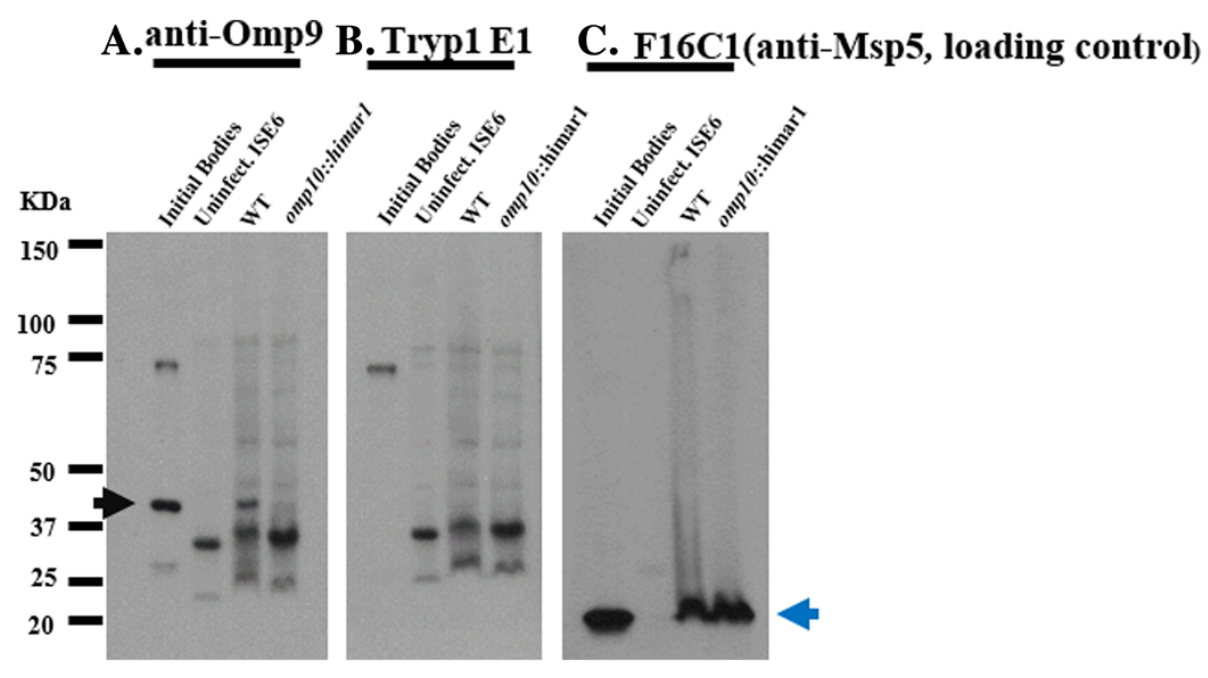

Figure 8 Immunoblotting of omp10::himar1 mutant and WT A. marginale using the specific monoclonal antibody Omp9. Proteins from equal amounts of host cell-free wild-type (WT) and omp10:"himar1 A. marginale were separated by SDS-PAGE gel electrophoresis. Immunoblot PVDF membranes of transferred proteins were reacted with monoclonal antibodies and reactions were visualized by chemiluminescence. A. Monoclonal antibody Omp9 $(4 \mathrm{\mu g} / \mathrm{ml})$ with specificity to Omp9 protein (40 kDa) (black arrow). B. Negative control, monoclonal Tryp1E1 (4 $\mu \mathrm{g} / \mathrm{ml})$ (exhibits specificity for a variable surface glycoprotein of Trypanosoma brucei. C. Monoclonal F16C1 (2 $\mu \mathrm{g} / \mathrm{ml})$, reacts with the Msp5 (19 kDa) (blue arrow) protein of A. marginale, was used as loading control. A. marginale str. Virginia and uninfected ISE6 cells were used as positive and negative controls respectively.

Sequencing analysis determined that the transposon sense strand is found in the opposite orientation to omp10, so it might be possible for transcription to read through the Himar1 sequences and produce anti-sense transcripts that could reduce expression of sequences upstream of omp10, but to demonstrate this further characterization is required.

Western immunoblot analysis showed that the transposon insertion into omp10 markedly reduced protein expression of omp 9 in the omp10::himar1 mutant $A$. marginale when compared to wild-type, corroborating that both mRNA and protein expression from genes downstream of omp10 were disrupted.

The evidence presented here suggests that these genes are not essential for growth of $A$. marginale in tick cell culture. Significant work on the possible interactions between the expressed proteins in different host environments has accumulated and offers important clues about the possible phenotypic effects of the disruption of these genes in A. marginale. For example omp7, omp 8 , omp 9 and omp 10 are differentially expressed in tick and mammalian cells with lower levels in tick midgut and cultured tick cells [43]. Detection of proteins from these genes has been reported [43,47,48]. Omp7, Omp8 and Omp9 are conserved during tick transmission and in acute and persistently infected cattle [43]. Characterization of the repertoire of outer membrane surface proteins by mass spectrometry identified Omp10 and Omp7 as immunogenic in cattle [47]. Proteome analysis using crosslinking and liquid chromatography-mass spectrometry (LC-MS/MS) to determine the composition and topological organization of surface proteins in A. marginale in mammalian and tick cells isolated a large protein complex and analysis demonstrated that
Omp7, Omp8 and Omp9 are arranged in the outer membrane as near neighbors to Msp2, Msp3, Msp4, Omp1, Opag2, Am779, Am780, Am1011, Am854 and VirB1 in A. marginale isolated from erythrocytes [18]. In contrast a similar sized large protein complex in A. marginale isolated from tick cells was formed only by Msp2, Msp3, Msp4, Am778 and Am854. Although Omp7, Omp8 and Omp9 were expressed they did not seem to be localized to the surface, suggesting a possible re-arrangement in the topology of the surface of $A$. marginale during the transition from the tick cell into the mammalian cell [18].

Interestingly, the number of Msp2 superfamily members such as omp1 to omp15 in A. marginale subsp. centrale, is reduced in comparison with US $A$. marginale strains [10]. For example, closely related sequences to omp 8 and omp 6 are missing and omp10 is found with omp 7 and a reduced omp 9 in tandem, which may indicate an important function of these genes in the pathogenicity of $A$. marginale.

Based on this, further characterization of these omp10::himar1 mutants to understand the effects of the disruption of expression of omp10, 9, 8 and 7 on the phenotype of $A$. marginale is of critical importance. Phenotypic effects may include infectivity, tick transmissibility, stability under non selectable conditions, ability to induce immune responses and ability to establish persistent infection within the natural host.

\section{Conclusions}

Transposon mutagenesis is achievable for A. marginale. High throughput genome sequencing of recombinant bacteria electroporated with a single plasmid containing 
the Himar1 sequences and the $A 7$ transposase showed insertion of the Himar1 sequences into the omp10 gene of $A$. marginale. The insertion was mediated by the transposase in a cut and paste mechanism. In tick cells omp10 is expressed as a polycistronic message with AM1225 at the 5'end and omp9, 8 and 7 at the 3' end. Insertion of the Himar 1 transposon within omp10 not only disrupted its expression but also the expression of genes downstream, such as omp9, omp8 and omp7.

This work shows the utility of the Himarl system for the generation of insertional mutants in A. marginale, for the identification of genes involved in virulence and potentially for the development of attenuated organisms.

\section{Methods}

\section{A. marginale cultivation}

Cultures of $A$. marginale str. Virginia wild-type and omp10::himar1 mutant were maintained in tick ISE6 cells derived from embryonated eggs of the blacklegged tick, Ixodes scapularis at $34^{\circ} \mathrm{C}$ in non-vented $25-\mathrm{cm}^{2}$ cell culture flasks (NUNC). A. marginale-infected cell cultures were maintained in L15B300 medium supplemented with $5 \%$ fetal bovine serum (FBS, BenchMark, Gemini BioProducts), 5\% tryptose phosphate broth (TPB, Difco, Becton Dickinson), 0.1\% bovine lipoprotein concentrate (LPC, MP-Biomedical), $0.25 \% \mathrm{NaHCO}_{3}$, and $25 \mathrm{mM}$ HEPES buffer, adjusted to $\mathrm{pH} 7.8$, as previously described [49]. The cell culture medium for ISE6 cells infected with the A. marginale omp10::himar1 mutant was supplemented with spectinomycin (Sigma Aldrich) and streptomycin (Sigma Aldrich) to a final concentration of $50 \mu \mathrm{g} / \mathrm{ml}$ each.

\section{Isolation of the $A$. marginale mutant by transposon mutagenesis}

To maximize chances of obtaining a transformant using transposon mutagenesis, we used a single plasmid construct that encoded both the transposon and the transposase in cis configuration as described [50], except that the fluorescent marker was replaced by sequences encoding a monomeric red fluorescent protein, mCherry [51] (Figure 1A). A. marginale bacteria passaged 53 times in ISE6 cells were harvested from one $25-\mathrm{cm}^{2}$ culture in $5 \mathrm{ml}$ of medium when $\sim 80 \%$ of cells were infected, and many cells were undergoing lysis. The cells were recovered in $2 \mathrm{ml}$ of culture medium, and added to a 2-ml microcentrifuge tube containing $0.3 \mathrm{ml}$ of sterile silicon carbide abrasive (60/90 grit; Lortone, Inc), vortexed at maximum speed for $30 \mathrm{sec}$, and the lysate transferred to a fresh 2-ml tube on ice. Bacteria were collected by centrifugation at $11,000 \mathrm{~g}$ for $10 \mathrm{~min}$ at $4^{\circ} \mathrm{C}$, and washed twice in ice-cold $300 \mathrm{mM}$ sucrose. They were then resuspended in $50 \mu \mathrm{l}$ of $300 \mathrm{mM}$ sucrose containing $3 \mu \mathrm{g}$ of plasmid DNA, and incubated on ice for $15 \mathrm{~min}$ before being electroporated (Biorad Gene Pulser II) at $2 \mathrm{kV}, 400 \mathrm{Ohm}$ and $25 \mu \mathrm{F}$ in a $0.2 \mathrm{~cm}$ gap cuvette. The electroporation mixture was recovered in $1.5 \mathrm{ml}$ of an ISE6 cell suspension $\left(\sim 2 \times 10^{6}\right.$ cells $)$, and centrifuged in a microcentrifuge tube at $1,000 \mathrm{~g}$ for $10 \mathrm{~min}$ at room temperature. The tube was left undisturbed for $30 \mathrm{~min}$ at room temperature, and the pellet then resuspended in the supernatant medium and added to a $25-\mathrm{cm}^{2}$ flask containing $\sim 5 \times 10^{6}$ ISE6 cells in $3 \mathrm{ml}$ of L15B300 medium supplemented as described for Anaplasmainfected cultures. The culture was incubated at $34^{\circ} \mathrm{C}$ in a tightly capped flask. Three days after electroporation, the culture medium was replaced with $5 \mathrm{ml}$ of medium additionally containing $50 \mu \mathrm{g} / \mathrm{ml}$ of spectinomycin and streptomycin (selection medium). Subsequently, the culture was fed twice weekly with selection medium and examined weekly on an inverted microscope (Diaphot, Nikon) fitted for epifluorescence using a Texas Red filter. The first fluorescent colonies of bacteria were noted $6 \mathrm{wk}$ following electroporation, and the culture was maintained in selection medium with twice-weekly medium changes until $\sim 90 \%$ of cells were infected. At that time, the mutant was passaged (ten-fold dilution) to fresh cells, and the remainder was stored in liquid nitrogen.

\section{Preparation of host cell-free $A$. marginale wild-type and omp10::himar1 mutant from ISE6 tick cells}

Isolation of $A$. marginale wild-type and omp10::himar1 mutant was performed by disruption of ISE6 tick cells with $1 \mathrm{~mm}$ diameter glass beads (BioSpec Technologies) in a Minibead beater (BioSpec technologies) as described elsewhere [52], with the exception that cells were shaken only once for $10 \mathrm{~s}$ and immediately placed on ice. Cell lysates were transferred to $1.5 \mathrm{ml}$ centrifuge tubes and centrifuged at $100 \mathrm{~g}$ for $5 \mathrm{~min}$ at $4^{\circ} \mathrm{C}$ to pellet cell debris. The supernatant was then carefully removed and transferred to clean $1.5 \mathrm{ml}$ centrifuge tubes. A. marginale organisms (wild-type and omp10::himar1 mutant) were pelleted at $11,000 \mathrm{~g}$ for $10 \mathrm{~min}$ at $4^{\circ} \mathrm{C}$, and stored at $-20^{\circ} \mathrm{C}$.

\section{DNA isolation and Phi29 amplification of the A. marginale omp10::himar1 mutant}

Before DNA isolation, pelleted A. marginale omp10:: himar1 mutants were treated with RNaseA (QIAGEN) and DNase I (Sigma Aldrich) to remove ISE6 host cell contaminant nucleic acids. DNA isolation was performed using the QIAamp DNA Mini kit (QIAGEN) as per manufacturer's instructions, but in this case the DNA was eluted in $50 \mu \mathrm{l}$ of $1 \mathrm{mM}$ Tris $\mathrm{pH}$ 9.0. DNA concentration was determined using the Qubit dsDNA HS assay kit (Life technologies) on a Qubit fluorometer (Life technologies). 5 reactions of $10 \mathrm{ng}$ of DNA were used for whole genome amplification using the Genomi Phi V2 DNA amplification kit (GE Healthcare) according to manufacturer's 
instructions. Following amplification, aliquots were pooled together and the DNA purified with GelElute Extraction Kit (5 PRIME) by adsorption to silica particles and eluted with $10 \mathrm{mM}$ Tris pH8.2.

\section{Genome sequencing and bioinformatics}

Samples from 2.0 to $3.6 \mu \mathrm{g}$ of amplified DNA derived from the omp10::himar1 mutant, were provided for library construction and sequencing by the Roche/454 (GS-FLX) method to the Interdisciplinary Center for Biotechnology Research (ICBR) at the University of Florida. Also, samples of equivalent amounts were provided to the Scripps Research Institute, La Jolla, California for sequencing by the Illumina (HiSeq) method.

A total of 374,151 and 207,288,916 reads of Roche/454 and Illumina sequencing data, respectively, were obtained. The FASTQ files provided by the sequencing facilities were uploaded to the UF GALAXY web site http://galaxy. hpc.ufl.edu, and analyzed separately.

Uploaded Illumina FASTQ files were groomed, filtered and formatted into FASTA files using the FASTQ Groomer, Filter FASTQ and FASTQ to FASTA converter tools located in the NGS: QC and manipulation toolbox of GALAXY. FASTA files were then aligned to the A. marginale str. St Maries reference genome sequence (CP000030) using the Megablast alignment tool (NCBI BLAST + blastn (version 0.0.12) in GALAXY) to obtain sequencing reads that contained $A$. marginale sequences.

These $A$. marginale sequencing reads were then used for a second Megablast alignment using as a reference sequence 28 nucleotides from the Himar1 terminal inverted repeats (TIR). The transposon insertion locus within the $A$. marginale chromosome was then determined, since the reads obtained contained the $A$. marginale-Himar1 TIR junctions.

A similar strategy was used for the analysis of the Roche/454 sequencing reads. CLC genomics workbench, version 6.5 was used for assemblies of Roche/454 and Illumina reads.

\section{RNA isolation}

For RNA isolation, three samples of ISE6 cells infected with A. marginale wild-type and three omp10::himar1 samples were used. Each sample derived from separate cultures grown in T-25 cell culture flasks. Samples containing approximately equal numbers of infected cells were collected in RNA stabilization reagent RNAlater (AMBION-Life technologies) and stored at $-80^{\circ} \mathrm{C}$. Total RNA was isolated using the RNeasy kit (QIAGEN) with an added "on-column" DNase I treatment (QIAGEN) according to manufacturer's instructions. Aliquots of extracted RNA were used to measure contaminant DNA concentration using the Qubit dsDNA HS assay kit (Life technologies). Additionally, RNA was treated three times with RNase-free Dnase I (AMBION-Life technologies) to remove any trace of contaminant DNA in the sample. RNA concentration was measured with the Qubit RNA assay kit (Life technologies), and samples were stored at $-80^{\circ} \mathrm{C}$.

\section{RT-PCR and RT-qPCR experiments}

RNA (2 $\mu \mathrm{g})$ from ISE6 cells infected with $A$. marginale wild-type and omp10::himar1 mutant was converted to cDNA by random priming using a Omniscript reverse transcriptase kit (QIAGEN) according to manufacturer's conditions. Genomic DNA and no-reverse transcriptase reactions were included as controls for each sample and each nucleic acid target. Specific primers (Table 1) were designed to amplify transcripts from intergenic regions between omp7-omp8, omp8-omp9, omp9-omp10 and omp10-AM1225 using cDNA from ISE6 cells infected with $A$. marginale wild-type as template. Similarly transcripts from within omp6, omp7, omp8, omp9, and omp10 genes were detected by PCR amplification of cDNA from ISE6 cells infected with $A$. marginale wildtype and the omp10::himar1 mutant using omp6-10 specific primers (Table 1). PCR amplification conditions for each PCR experiment are described in Additional file 1: Tables S1 and S2 respectively.

\section{RT-qPCR experiments}

Transcript differences between omp8, omp9, omp10-5' end, and omp10-3' genes in A. marginale wild-type and omp10::himar1 mutant were determined using the comparative $2^{-\Delta \Delta C t}$ method $[53,54]$ and the results were based on the mean of three biological samples (individual RNA extracts). For Taqman quantitative PCR, cDNA obtained from ISE6 cells infected with A. marginale wild-type and the omp10::himar1 was used with primers and probes (Table 1) designed to amplify omp8, omp9, omp10-5' end, omp10-3' end, msp5, rpoH and the $16 S$ gene sequences. Reaction conditions are described in Additional file 1: Table S3, specificity of primers and probes is shown in Additional file 1: Figure S1 and the amplification efficiencies for each target are reported in Additional file 1: Table S4. For a valid $2^{-\Delta \Delta C t}$ calculation, relative efficiencies of target vs. reference genes were calculated and are reported in Additional file 1: Table S5.

Significant differences between the A. marginale wildtype and omp10::himar1 mutant were calculated by Student's $\mathrm{t}$ test $(\mathrm{P}<0.05)$, comparing $\Delta \mathrm{Ct}$ values (target gene- reference gene) of the omp10::himar1 mutant and the wild-type. The fold difference was based on $\Delta \Delta \mathrm{Ct}$ (omp10::himar1 mean $\Delta \mathrm{Ct}$ - wild-type mean $\Delta \mathrm{Ct}$ ) and calculated as $2^{-\Delta \Delta C t}$ which yields the expression ratio. The expression ratio was then expressed as percentage of expression by multiplying the $2^{-\Delta \Delta \mathrm{Ct}}$ values by 100 . For normalization of relative gene expression data $m s p 5$ [55], $r p o H$, and $16 S$ were used as reference genes. 
Table 1 PCR and Taqman qPCR oligonucleotides used in this study

\begin{tabular}{|c|c|c|c|c|}
\hline \multicolumn{2}{|c|}{ Oligonucleotide sequence $\left(5^{\prime}\right.$ to $\left.3^{\prime}\right)$} & \multirow[t]{2}{*}{ Target } & \multirow[t]{2}{*}{ Size } & \multirow[t]{2}{*}{ Reference } \\
\hline PCR & & & & \\
\hline AB1553 & CTCCAATCGGAGGGGTTGTG & omp6 & 492bp & {$[43]$} \\
\hline AB1554 & GCATAAATCCAGTTAGCCTCC & & & \\
\hline AB1555 & GTGGTTAGATCTITTCTGTTGGG & omp7 & 399bp & {$[43]$} \\
\hline AB1556 & CGCTCTACCACTGACCTTCATG & & & \\
\hline AB1591 & GCTGGAGTTCGAAGCGATGC & omp8 & $259 \mathrm{bp}$ & This study \\
\hline AB1592 & CAGAGCGCCCTGTTCAGTG & & & \\
\hline AB1559 & AGCTGGGGCTCTTGCGTTG & omp9 & $1096 \mathrm{bp}$ & {$[43]$} \\
\hline AB1560 & AACATATTCACTATAATCTGACGCTGC & & & \\
\hline AB1561 & TCCTTCGGGTTGCTGCGTTG & omp10 & $969 \mathrm{bp}$ & {$[43]$} \\
\hline AB1562 & GCTTACCCCCATTCCAGCAC & & & \\
\hline AB1572 & AGGATGATCAGCCACACTGGAA & 165 & $131 \mathrm{bp}$ & This study \\
\hline AB1573 & TACAACCCTAAGGCCTTCCTCA & & & \\
\hline \multicolumn{5}{|l|}{$* * \mathrm{qPCR}$} \\
\hline AB1591 & GCTGGAGTTCGAAGCGATGC & & & \\
\hline AB1592 & CAGAGCGCCCTGTITCAGTG & omp8 & $259 b p$ & This study \\
\hline AB1593 & GCGTGAGCACTGCGGTACAGACGG & & & \\
\hline AB1581 & GAAGTCACTACACGACCTGACTGT & & & \\
\hline AB1582 & TAAAGCATCTTCGCGGGTCGT & omp9 & $145 \mathrm{bp}$ & {$[43]$} \\
\hline AB1583 & TATTCAGTGCGCTGAACACTGCGATCCA & & & \\
\hline AB1594 & GTGGGTGCTGTACGCACATT & & & \\
\hline AB1595 & AAAGACAGCAGGCAGCAACA & omp10-5' & $170 \mathrm{bp}$ & This study \\
\hline AB1596 & CGCGTGTCCTTCGGGTTGCT & & & \\
\hline AB1569 & GGTGCTGAGTTGAAGCTTGC & & & \\
\hline AB1570 & GCCACAGACCCACTATCAGC & omp10-3' & $140 \mathrm{bp}$ & {$[43]$} \\
\hline AB1571 & TATCTCGCGCTGCATCGGTG & & & \\
\hline AB1572 & AGGATGATCAGCCACACTGGAA & & & \\
\hline AB1573 & TACAACCCTAAGGCCTTCCTCA & 165 & $131 b p$ & {$[42]$} \\
\hline AB1574 & TATTGGACAATGGGCGCAAGCCTGAT & & & \\
\hline AB1606 & CTCACAGGCGAAGAAGCAGAC & & & \\
\hline AB1607 & GCCCGACATACCTGCCTIT & msp5 & $145 \mathrm{bp}$ & {$[55]$} \\
\hline AB1610 & TGGGCGACAAGAAGCCAAGTGA & & & \\
\hline AB1608 & ATCAAAGCTATTGCGGAGGA & & & \\
\hline AB1607 & ACAGAACTCTCCCCATGCAC & rpoH & $116 \mathrm{bp}$ & This study \\
\hline AB1611 & TGCCAATCGGGACGTTTCGC & & & \\
\hline AB1242 & AAAACAGGCTTACCGCTCCAA & & & \\
\hline AB1243 & GGCGTGTAGCTAGGCTCAAAGT & opag2 & $151 \mathrm{bp}$ & {$[41]$} \\
\hline AB1250 & CTCTCCTCTGCTCAGGGCTCTGCG & & & \\
\hline
\end{tabular}

*Primers and TaqMan probes used were manufactured at Eurofins MGM Operon.

Oligonucleotides are labeled with 6-Carboxyfluorescein 6-FAM at the $5^{\prime}$ end and Tetramethylrhodamine TAMRA at the $3^{\prime}$ end.

Western immunoblots

Expression of the Omp9 protein in A. marginale wildtype and omp10::himar1 mutant was assessed by sodium dodecyl sulfate-polyacrylamide gel electrophoresis and immunoblotting using equal amounts $\left(10^{8}\right)$ of host-free bacteria. Membranes were incubated with three different antibodies; the anti-Omp9 monoclonal antibody (121/1055) [43], the monoclonal antibody F16C1 (reacts with the Msp5 protein and served as a loading control) [56] and the monoclonal antibody Tryp1E1 (exhibits specificity for a 
variable surface glycoprotein of Trypanosoma brucei) [56]. This last antibody served as a negative control. Final concentrations of each antibody used were $4 \mu \mathrm{g} / \mathrm{ml}, 2 \mu \mathrm{g} / \mathrm{ml}$ and $4 \mu \mathrm{g} / \mathrm{ml}$. Antibody binding was detected with the secondary antibody goat anti-mouse IgG, horseradish peroxidase labeled and diluted to 1:10,000 using the Pierce ECL Western blotting substrate (Thermo scientific) as described in manufacturer's instructions.

Quantification of the number of $A$. marginale wildtype and omp10::himar1 organisms was performed as described elsewhere [41].

\section{GenBank accession numbers}

for assembled contigs containing the Himar1 transposon sequences integrated within omp10 and upstream genes (KJ567138) and omp10 (partial 3' end) and omp9 genes (KJ567139).

\section{Additional file}

Additional file 1: RT-PCR and RT-qPCR experiments Figure and Tables.

\section{Competing interests}

The authors declare that they have no competing interests.

\section{Authors' contributions}

FLC designed and carried out experiments, data analysis and authored this manuscript. HLW and MGP carried out tick cell media preparation, maintenance of uninfected tick cell cultures and co-authored the manuscript. AML performed Western blot experiments and co-authored the manuscript. AFB advised on experiments, genome sequencing analysis, critically evaluated and co-authored the manuscript. SMN provided monoclonal antibodies for Western blot experiments, co-authored and critically evaluated the manuscript. UM kindly provided transformed A. marginale organisms co-authored and critically evaluated the manuscript. All authors read and approved the final manuscript.

\section{Acknowledgments}

This work received support from grant number GR075800M from the Wellcome Trust.

\section{Author details}

${ }^{1}$ College of Veterinary Medicine, University of Florida, Department of Infectious Diseases and Pathology, 2015 SW 16th avenue, Gainesville, FL 32610, USA. ² Physiological Sciences, 2015 SW 16th avenue, Gainesville, FL 32610, USA. ${ }^{3}$ USDA-ARS Animal Disease Research Unit, Animal Disease Research Unit, 3003 ADBF, Pullman, WA 99164, USA. ${ }^{4}$ Department of Entomology, University of Minnesota, 219 Hodson Hall 1980 Folwell avenue, St. Paul, Minneapolis, MN 55108, USA.

Received: 23 October 2013 Accepted: 31 March 2014 Published: 11 April 2014

\section{References}

1. Kocan KM, de la Fuente J, Blouin EF, Coetzee JF, Ewing SA: The natural history of Anaplasma marginale. Vet Parasitol 2010, 167:95-107.

2. Kocan KM, de la Fuente J, Blouin EF, Garcia-Garcia JC: Anaplasma marginale (Rickettsiales: Anaplasmataceae): recent advances in defining host-pathogen adaptations of a tick-borne rickettsia. Parasitology 2004, 129(Suppl):S285-300

3. Morley RS, Hugh-Jones ME: The cost of anaplasmosis in the Red River Plains and south-east areas of Louisiana. Vet Res Commun 1989, $13: 349-358$
4. Goodger WJ, Carpenter T, Riemann H: Estimation of economic loss associated with anaplasmosis in California beef cattle. J Am Vet Med Assoc 1979, 174:1333-1336.

5. Palmer $\mathrm{GH}$, Brayton KA: Antigenic variation and transmission fitness as drivers of bacterial strain structure. Cell Microbiol 2013, 12:1969-1975. doi:10.1128/CVI.00600-12.

6. Palmer GH, Futse JE, Knowles DP Jr, Brayton KA: Insights into mechanisms of bacterial antigenic variation derived from the complete genome sequence of Anaplasma marginale. Ann N Y Acad Sci 2006, 1078:15-25.

7. Meeus PF, Brayton KA, Palmer GH, Barbet AF: Conservation of a gene conversion mechanism in two distantly related paralogues of Anaplasma marginale. Mol Microbiol 2003, 47:633-643.

8. Meeus PF, Barbet AF: Ingenious gene generation. Trends Microbiol 2001 9:353-355. discussion 355-356.

9. Kocan KM, de la Fuente J, Guglielmone AA, Melendez RD: Antigens and alternatives for control of Anaplasma marginale infection in cattle. Clin Microbiol Rev 2003, 16:698-712.

10. Herndon DR, Palmer GH, Shkap V, Knowles DP Jr, Brayton KA: Complete genome sequence of Anaplasma marginale subsp. centrale. J Bacteriol 2010, 192:379-380.

11. Agnes JT, Brayton KA, LaFollett M, Norimine J, Brown WC, Palmer GH: Identification of Anaplasma marginale outer membrane protein antigens conserved between $A$. marginale sensu stricto strains and the live $A$. marginale subsp. centrale vaccine. Infect Immun 2011, 79:1311-1318.

12. Dark MJ, Al-Khedery B, Barbet AF: Multistrain genome analysis identifies candidate vaccine antigens of Anaplasma marginale. Vaccine 2011, 29:4923-4932.

13. de la Fuente J, Kocan KM, Garcia-Garcia JC, Blouin EF, Claypool PL, Saliki JT: Vaccination of cattle with Anaplasma marginale derived from tick cell culture and bovine erythrocytes followed by challenge-exposure with infected ticks. Vet Microbiol 2002, 89:239-251.

14. Rodriguez SD: Garcia Ortiz MA, Hernandez Salgado G, Santos Cerda NA, Aboytes Torre R, Canto Alarcon GJ: Anaplasma marginale inactivated vaccine: dose titration against a homologous challenge. Comp Immunol Microbiol Infect Dis 2000, 23:239-252.

15. Kano FS, Tamekuni K, Coelho AL, Garcia JL, Vidotto O, Itano EN, Vidotto MC: Induced immune response of DNA vaccine encoding an association MSP1a, MSP1b, and MSP5 antigens of Anaplasma marginale. Vaccine 2008, 26:3522-3527.

16. Brown WC, Shkap V, Zhu D, McGuire TC, Tuo W, McElwain TF, Palmer GH: $\mathrm{CD}^{(+)}$T-lymphocyte and immunoglobulin $\mathrm{G} 2$ responses in calves immunized with Anaplasma marginale outer membranes and protected against homologous challenge. Infect Immun 1998, 66:5406-5413.

17. Brown WC, Zhu D, Shkap V, McGuire TC, Blouin EF, Kocan KM, Palmer GH: The repertoire of Anaplasma marginale antigens recognized by CD4(+) T-lymphocyte clones from protectively immunized cattle is diverse and includes major surface protein 2 (MSP-2) and MSP-3. Infect Immun 1998, 66:5414-5422.

18. Noh SM, Brayton KA, Brown WC, Norimine J, Munske GR, Davitt CM, Palmer GH: Composition of the surface proteome of Anaplasma marginale and its role in protective immunity induced by outer membrane immunization. Infect Immun 2008, 76:2219-2226.

19. Noh SM, Turse JE, Brown WC, Norimine J, Palmer GH: Linkage between Anaplasma marginale outer membrane proteins enhances immunogenicity but is not required for protection from challenge. Clin Vaccine Immunol 2013, 20:651-656.

20. Sutten EL, Norimine J, Beare PA, Heinzen RA, Lopez JE, Morse K, Brayton KA, Gillespie JJ, Brown WC: Anaplasma marginale type IV secretion system proteins VirB2, VirB7, VirB11, and VirD4 are immunogenic components of a protective bacterial membrane vaccine. Infect Immun 2010, 78:1314-1325.

21. Brayton KA, Kappmeyer LS, Herndon DR, Dark MJ, Tibbals DL, Palmer GH, McGuire TC, Knowles DP Jr: Complete genome sequencing of Anaplasma marginale reveals that the surface is skewed to two superfamilies of outer membrane proteins. Proc Natl Acad Sci U S A 2005, 102:844-849.

22. Palmer GH, Brown WC, Noh SM, Brayton KA: Genome-wide screening and identification of antigens for rickettsial vaccine development. FEMS Immunol Med Microbiol 2012, 64:115-119.

23. Dark MJ, Lundgren AM, Barbet AF: Determining the repertoire of immunodominant proteins via whole-genome amplification of intracellular pathogens. PLOS One 2012, 7:e36456. doi:10.1371/journal.pone.0036456 
24. Brayton KA, Palmer GH, Brown WC: Genomic and proteomic approaches to vaccine candidate identification for Anaplasma marginale. Expert Rev Vaccines 2006, 5:95-101.

25. Pierle SA, Dark MJ, Dahmen D, Palmer GH, Brayton KA: Comparative genomics and transcriptomics of trait-gene association. BMC Genomics 2012, 13:669.

26. Van Opijnen T, Camilli A: Transposon insertion sequencing: a new tool for systems-level analysis of microorganisms. Nat Rev Microbiol 2013, 11:435-442.

27. Claeys Bouuaert C, Chalmers RM: Gene therapy vectors: the prospects and potentials of the cut-and-paste transposons. Genetica 2010, 138:473-484

28. Picardeau M: Transposition of fly mariner elements into bacteria as a genetic tool for mutagenesis. Genetica 2010, 138:551-558.

29. Lampe DJ, Grant TE, Robertson HM: Factors affecting transposition of the Himar1 mariner transposon in vitro. Genetics 1998, 149:179-187.

30. Plasterk RH, Izsvak Z, Ivics Z: Resident aliens: the Tc1/mariner superfamily of transposable elements. Trends Genet 1999, 15:326-332.

31. Clark TR, Ellison DW, Kleba B, Hackstadt T: Complementation of Rickettsia rickettsii RelA/SpoT restores a nonlytic plaque phenotype. Infect Immun 2011, 79:1631-1637.

32. Clark TR, Lackey AM, Kleba B, Driskell LO, Lutter El, Martens C, Wood DO, Hackstadt T: Transformation frequency of a mariner-based transposon in Rickettsia rickettsii. J Bacteriol 2011, 193:4993-4995.

33. Kleba B, Clark TR, Lutter El, Ellison DW, Hackstadt T: Disruption of the Rickettsia rickettsii Sca2 autotransporter inhibits actin-based motility. Infect Immun 2010, 78:2240-2247.

34. Beare PA, Sandoz KM, Omsland A, Rockey DD, Heinzen RA: Advances in genetic manipulation of obligate intracellular bacterial pathogens. Front Microbiol 2011, 2:97

35. Beare PA: Genetic manipulation of Coxiella burnetii. Adv Exp Med Biol 2012, 984:249-271.

36. Botkin DJ, Abbott AN, Stewart PE, Rosa PA, Kawabata H, Watanabe H, Norris SJ: Identification of potential virulence determinants by Himar1 transposition of infectious Borrelia burgdorferi B31. Infect Immun 2006, 74:6690-6699.

37. Stewart PE, Hoff J, Fischer E, Krum JG, Rosa PA: Genome-wide transposon mutagenesis of Borrelia burgdorferi for identification of phenotypic mutants. Appl Environ Microbiol 2004, 70:5973-5979.

38. Maier TM, Casey MS, Becker RH, Dorsey CW, Glass EM, Maltsev N, Zahrt TC, Frank DW: Identification of Francisella tularensis Himar1-based transposon mutants defective for replication in macrophages. Infect Immun 2007, 75:5376-5389.

39. Cheng C, Nair AD, Indukuri W, Gong S, Felsheim RF, Jaworski D, Munderloh UG, Ganta RR: Targeted and random mutagenesis of Ehrlichia chaffeensis for the identification of genes required for in vivo infection. PLOS Pathog 2013, 9:e1003171. doi:10.1371/journal.ppat.1003171.

40. Felsheim RF, Herron MJ, Nelson CM, Burkhardt NY, Barbet AF, Kurtti TJ, Munderloh UG: Transformation of Anaplasma phagocytophilum. BMC Biotechnol 2006, 6:42.

41. Felsheim RF, Chavez AS, Palmer GH, Crosby L, Barbet AF, Kurtti TJ, Munderloh UG: Transformation of Anaplasma marginale. Vet Parasitol 2010, 167:167-174

42. Barbet AF, Agnes JT, Moreland AL, Lundgren AM, Alleman AR, Noh SM, Brayton KA, Munderloh UG, Palmer GH: Identification of functional promoters in the msp2 expression loci of Anaplasma marginale and Anaplasma phagocytophilum. Gene 2005, 353:89-97.

43. Noh SM, Brayton KA, Knowles DP, Agnes JT, Dark MJ, Brown WC, Baszler TV, Palmer GH: Differential expression and sequence conservation of the Anaplasma marginale msp2 gene superfamily outer membrane proteins. Infect Immun 2006, 74:3471-3479.

44. Guell M, van Noort V, Yus E, Chen WH, Leigh-Bell J, Michalodimitrakis K, Yamada T, Arumugam M, Doerks T, Kuhner S, Rode M, Suyama M, Schmidt S, Gavin AC, Bork P, Serrano L: Transcriptome complexity in a genome-reduced bacterium. Science 2009, 326:1268-1271.

45. Kleckner N: Translocatable elements in procaryotes. Cell 1977, 11:11-23.

46. Beare PA, Gilk SD, Larson CL, Hill J, Stead CM, Omsland A, Cockrell DC, Howe D, Voth DE, Heinzen RA: Dot/Icm type IVB secretion system requirements for Coxiella burnetii growth in human macrophages. MBio 2011, 2:e00175-00111.

47. Lopez JE, Siems WF, Palmer GH, Brayton KA, McGuire TC, Norimine J, Brown WC Identification of novel antigenic proteins in a complex Anaplasma marginale outer membrane immunogen by mass spectrometry and genomic mapping. Infect Immun 2005, 73:8109-8118.
48. Riding G, Hope M, Waltisbuhl D, Willadsen P: Identification of novel protective antigens from Anaplasma marginale. Vaccine 2003, 21:1874-1883.

49. Munderloh UG, Blouin EF, Kocan KM, Ge NL, Edwards WL, Kurtti TJ: Establishment of the tick (Acari:Ixodidae)-borne cattle pathogen Anaplasma marginale (Rickettsiales:Anaplasmataceae) in tick cell culture. J Med Entomol 1996, 33:656-664.

50. Munderloh UG FR, Burkhardt NY, Herron MJ, Olivia Chavez AS, Nelson CM, Kurtti TJ: The way forward: improving genetic systems. In Intracellular Pathogens II. Edited by Azad A, Palmer G. Washington, DC: ASM Press; 2012:416-432

51. Shanner N, Campbell RE, Steinbach PA, Giepmans BN, Palmer AE, Tsien RY: Improved monomeric red, orange and yellow fluorescent proteins derived from Discosoma sp. red fluorescent protein. Nat Biotechnol 2004, 22:5.

52. Qin A, Tucker AM, Hines A, Wood DO: Transposon mutagenesis of the obligate intracellular pathogen Rickettsia prowazekii. Appl Environ Microbiol 2004, 70:2816-2822.

53. Schmittgen TD, Livak KJ: Analyzing real-time PCR data by the comparative C(T) method. Nat Protoc 2008, 3:1101-1108.

54. Livak KJ, Schmittgen TD: Analysis of relative gene expression data using real-time quantitative PCR and the $2^{-\Delta \Delta C t}$ Method. Methods 2001, 25:402-408

55. Lohr CV, Rurangirwa FR, McElwain TF, Stiller D, Palmer GH: Specific expression of Anaplasma marginale major surface protein 2 salivary gland variants occurs in the midgut and is an early event during tick transmission. Infect Immun 2002, 70:114-120.

56. Barbet AF, Blentlinger R, Yi J, Lundgren AM, Blouin EF, Kocan KM: Comparison of surface proteins of Anaplasma marginale grown in tick cell culture, tick salivary glands, and cattle. Infect Immun 1999, 67:102-107.

doi:10.1186/1471-2164-15-278

Cite this article as: Crosby et al:: Knockout of an outer membrane protein operon of Anaplasma marginale by transposon mutagenesis. BMC Genomics 2014 15:278.

\section{Submit your next manuscript to BioMed Central and take full advantage of:}

- Convenient online submission

- Thorough peer review

- No space constraints or color figure charges

- Immediate publication on acceptance

- Inclusion in PubMed, CAS, Scopus and Google Scholar

- Research which is freely available for redistribution 